Volume 12(2), 2018

Page: $131-152$

\title{
Liquidity Management in Islamic Banking: Issues and Challenges
}

\section{Siti Kholifatul Rizkiah¹}

\begin{abstract}
As a financial intermediation, banking industry has and will always be bound with mismatch maturity problem between asset and liabilities which leads to liquidity issue. This article uses a literature study to observe the current liquidity trend in Islamic banking, the issues faced by the existing Islamic liquidity instruments and ways to overcome it. It is found that the common issues associated with Islamic liquidity instruments are sharia issue, inactivity of its secondary market, key issues on short term sukuk issuance and difficulty of cross-border transactions. A better management on liquidity position and a more robust liquidity infrastructure are needed for a better liquidty management in Islamic banking industry.
\end{abstract}

Keywords: Islamic banking, liquidity, Islamic liquidity instrument

Abstrak: Sebagai intermediasi keuangan, industri perbankan selalu dihadapkan pada masalah perbedaan jatuh tempo antara aset dan liabilitas yang menyebabkan masalah likuiditas. Artikel ini menggunakan studi literatur untuk mengobservasi tren likuiditas bank syariah, masalah yang muncul pada instrument manajemen likuiditas syariah dan solusi untuk mengatasi masalah tersebut. Masalah yang dihadapi oleh kebanyakan instrumen menejemen likuiditas adalah terkait dengan isu syariah, ketidak aktifan pasar sekunder, isu dalam penerbitan sukuk jangka pendek, dan tantangan transaksi antar negara. Diperlukan manajemen posisi likuiditas yang lebih baik di perbankan syariah dan infrastruktur likuiditas yang lebih matang untuk mewujudkan menejemen likuiditas yang baik di industri perbankan syariah.

Kata kunci: perbankan syariah, likuiditas, manajemen likuiditas syariah

${ }^{1}$ International Centre for Education in Islamic Finance, Malaysia | skrizkiah@gmail.com 


\section{Introduction}

There is probably nothing more frightening than experiencing a bank run in our financial system. A bank run is when customers rush to withdraw their money because they expect the bank to fail which force bank to liquidate its asset at a loss and to fail (Diamond and Dybvig, 1983; Waldo, 1985; Postlewaite and Vives, 1987). There has been a number of banks runs that we witness in the last decade such as Northern Rock that represents the first bank run in the UK history since 1866 (The Economist, 2007) and EuroBlown phenomena where a quarter of all deposits were withdrawn from Greek banks in two years in the year 2011 (Nymag, 2010).

Despite the many previous works of literature that argues conventional banking structure are more unstable and the system itself prone to crisis as compared to Islamic banking (Samad and Hassan, 1999; Beck et al., 2013), the bank run episode does not happen only in the conventional bank. A famous case of bank run did happen in the Islamic banking history in the year 2011 in Ihlas Finans House in Turkey (Hayali et al., 2012). When many banks in an economy system suffer a bank run at the same time, it can cause bank panic with a disruption in the monetary system.

A bank run can happen because banks normally keep only a small proportion of their deposit as cash (Bryant, 1980). This is done to make sure they can be efficient in using the deposit of customers to generate a maximum income. However, a bank should not only focus on profit maximization but they also have to be able to meet the withdrawal request from its customer. Although there are preemptive actions to combat bank run such as withdrawal limit, a good liquidity management should be practiced by all banks. According to a survey of industry practitioners and leaders of Middle East Islamic Financial Institutions that was conducted by Deloitte (2010), liquidity ratio was considered as the top priority in the banking industry. 
The purpose of this paper is to present a global view of liquidity management in Islamic banks, analyze the current liquidity management instruments available in the market, and highlight the issues and challenges. The rest of the paper is organized as follows: Section Two gives an overall overview of the theoretical foundation and highlight policy framework of liquidity management in banking industry. Section Three describes the research methodology used in this study. Section Four analyse the current state, issues and some alternatives for the improvement of liquity management in Islamic banking. Section Five concludes the study with policy implications.

\section{Literature Review}

This section would provide a theoritical foundation on the importance and relevance of liquidity risk in banking industry in general. It will also explain the existing regulatory framework on liquidity management that banking industry has to follow based on Basel III requirement.

As discuss in the previous part, Banks face a huge potential liquidity risk from their inability to meet their liability obligation when its due without incurring large losses in converting their asset into cash (Comptroller of the Currency, 2001). This liquidity risk comes from the nature of the Banking business in itself. Banks channel the fund deposited by customers to make a loan and earn some profit from there. Majority of the fund used in the business comes from depositors which are composed mainly of demand deposit. Due to this fact, it is important for them to make sure that they are able to meet the request from the depositors' withdrawal demand at timely maner.

It can also be said that the liquidity risk in banking industry originates from the mismatch of maturities between assets and liabilities (Sobol, 2013). The asset side of Bank's financial statement is predominantly composed of medium and long-term financing, while the liability primarily consists of shortterm demand deposit. This gap in maturities between assets and liabilities creates the risk of not able to meet the requested payment from the depositors (Kashyap et al., 2002). This will force a bank to convert or sell their asset into 
cash with a price much lower than the market price which is a loss to the bank (Muranaga and Ohsawa, 2002).

A question of why liquidity issue is so important to the banking industry can be answered by the impact of a bank run to the whole financial system in the country. When a bank collapse because it suffers a run, it will create a mistrust of society to banking institutions which can lead to a systemic bank run (Brown and Vlahu, 2016). Systemic bank runs or also called as bank panic is a situation where depositors are lack of information of the unobservable shock across banks and led them withdrawing their deposit because of fear that their bank will be unable to repay their deposit (Calomiris and Golton, 1991). Bank panic can cause a costly impact such as disruptions of a payment system, and credit supply, failure of banks, and suspension of bank debt convertibility (Calomiris and Mason, 1994).

However, it is also important to point out that an excessive liquidity is not profitable for the Bank either (Eljelly, 2004; and Olagunju et. al., 2012). For a business that uses depositors money to make a loan and gain profit, holding an excessive cash is part of inefficiency for the bank. The bank should maximize the fund that it has for productive and profit earning means. Since liquidity comes at a cost, a bank should find a balance between the safety of holding enough liquid asset and the expense of it (Bordeleau and Graham, 2010).

The last financial crisis in 2008 teaches us a lesson that the severity of a crisis was magnified by excessive leverage, inadequate and low-quality capital, and insufficient liquidity buffers (Basel, 2010). The Basel committee and its oversight body created a program to address the key lesson learned from financial crisis 2008 and establish a new framework to strengthen the resilience of banks the global banking system. The objective of this committee is to enhance understanding of a key supervisory issue and improve the quality of supervisory banking worldwide (BIS, 2016). The new global standards set Basel committee addresses firm-specific and systemic risk is what we know as Basel III. 
On of the three requirements in Basel III is to set the standard of global liquidity ratio (Gomes and Khan, 2011). The first liquidity requirement is liquidity coverage ratio. This ratio requires banks to have enough liquid assets to survive a 30-day market crisis. Elliott (2014) explained that 30 days was chosen as it is viewed to be long enough for the central bank and government to take necessary measures to stop a widespread market crisis of liquidity. The liquidity coverage ratio is calculated as high quality liquid asset divided by total net liquidity outflows over 30 days (Hong et al., 2014).

$$
L C R=\frac{\text { High quality liquid assets }}{\text { Total net liquidity outflows over } 30 \text { days }} \geq 100 \%
$$

High-Quality Liquid Asset (HQLA) are assets that can be easily converted to cash with little to no loss of value even during times of stress. HQLA is divided into two categories which are level 1 and level 2 (Bech and Keister, 2017). Level 1 HQLA compromises cash, central bank reserves, and securities issued by the central bank, government and some international finance agencies. Other qualifying liquid assets are put under level 2 category.

The second liquidity ratio set by Basel III is net stable funding ratio, this ratio is set to ensure banks' asset are supported by adequate stable funding sources (Hong et al., 2014). Stable funding sources include Tier 1 and Tier 2 capital, preferred equity and liabilities with maturity more than one year, and deposit with maturity less than one year but are expected to stay in the bank even in time of crisis. This ratio is done to keep banks from engaging in excessive maturity transformation that would be risky for them. It also encourages banks to use a longer-term funding and increase the issuance of investment account.

Despite the stability that is keen to be achieved by Basel III, Shearman and Sterling (2011) argued that application of Basel III is challenging -most especially the liquidity requirements. To meet the compliance of these liquidity requirements, Basel committee recommends an assessment of bank's contractual maturity mismatch, the concentration of funding, available 
unencumbered asset and ability to satisfy liquidity ratios in all relevant currencies (BIS, 2009). The implementation of Basel III has also bound to incur some significant costs to the bank.

Härle et al. (2010) from McKinsey Company estimate the implementation cost of regulatory compliance (Not including the cost to materially improve risk and finance capabilities, capital, funding and balance sheet management and to conduct portfolio moves) for a midsize European bank will be between $€ 45$ million to $€ 70$ million. Not only that, they also forecast that the implementation will require resources between 135 to 210 FTE years. However, Alkholifey, governor of the Saudi Arabian Monetary Authority on his speech at the 15th Islamic Financial Stability Forum mentioned that the high volume of regulations which take place after the global financial crisis 2008 would pay off despite a regulatory pause and increased compliance cost for banks (IFSB, 2017).

\section{Method}

This study explores the current state of liquidity management in Islamic banking industry and analyse the issues and challenges faced by the existing Islamic liquidity instruments. In doing so, this study uses a qualitative research by literature study. For this study, secondary data is obtained from relevant literatures such as books, academic researdh, industrial papers and other sources.

\section{Result and Discussion}

This section will explore the current state of liquidity management in Islamic banks, the issues and challenges faced by the existing Islamic liquidity instruments and a way forward towards a better liquidity management in Islamic banking industry.

\section{Liquidity Management in Islamic Banks}

In an ideal Islamic bank that uses profit and loss sharing system in their operation, should be more stable and not suffer liquidity problems (Sobol, 
2013). Under profit and loss sharing contracts such as musharrakah, the risk is shared proportionally by the bank, depositors, and borrowers. In case of mudhärabah contract, the risk associated with the fund is transferred fully to the fund owners or depositors. Any risk coming from the financing would eventually be being shared by all parties involved. While in the conventional bank that uses an interest-based system which makes the bank absorb all the risk alone. The default and problem on asset side will lead to an inability of meeting obligations on the liability side as the deposit principal is guaranteed.

Besides that, profit and loss sharing on deposit contracts has a longerterm maturity as it is an investment contract in nature. This nature of contract would solve the main problem of liquidity issue on the asset and liability mismatch. Unfortunately, profit and loss sharing is not the majority contracts used in Islamic banks (Dar and Parsley, 2000). Most of the deposit products in Islamic banks use contracts that behave like demand deposit such as qardh hassan and wadiah yad dammanah. These types of contracts have a short-term maturity as customers can withdraw their deposit at any time. While on the asset sides, Islamic banks use debt based contract such as murabahah, ijarah, salam, istisna and bay' muajjal which behaves similarly with debt based financing. Thus, the maturity mismatch between asset and liability still exists and Islamic bank still faces potential liquidity problem just like the conventional bank.

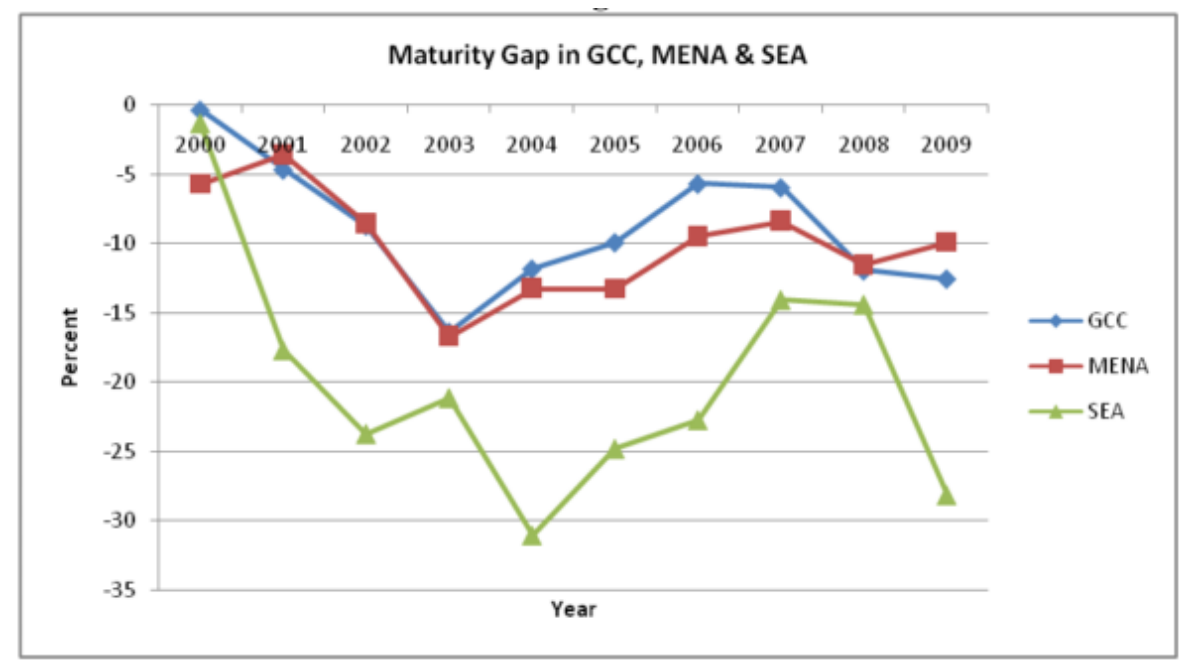

Figure 1. Maturity Gap in Islamic Banking Accros the Globes (Ali, 2013) 
According to Ali (2013), the South East Asia Islamic banks have the biggest maturity gap prior to financial crisis 2008 (Figure 1). This could be explained by the tendency of using debt-based funding and financing contracts instead of profit and loss sharing contract. At the same time, the infrastructure for Islamic liquidity management was almost non-existence. This gap has been tightened since 2008 following the initiative and innovation in sharia liquidity management.

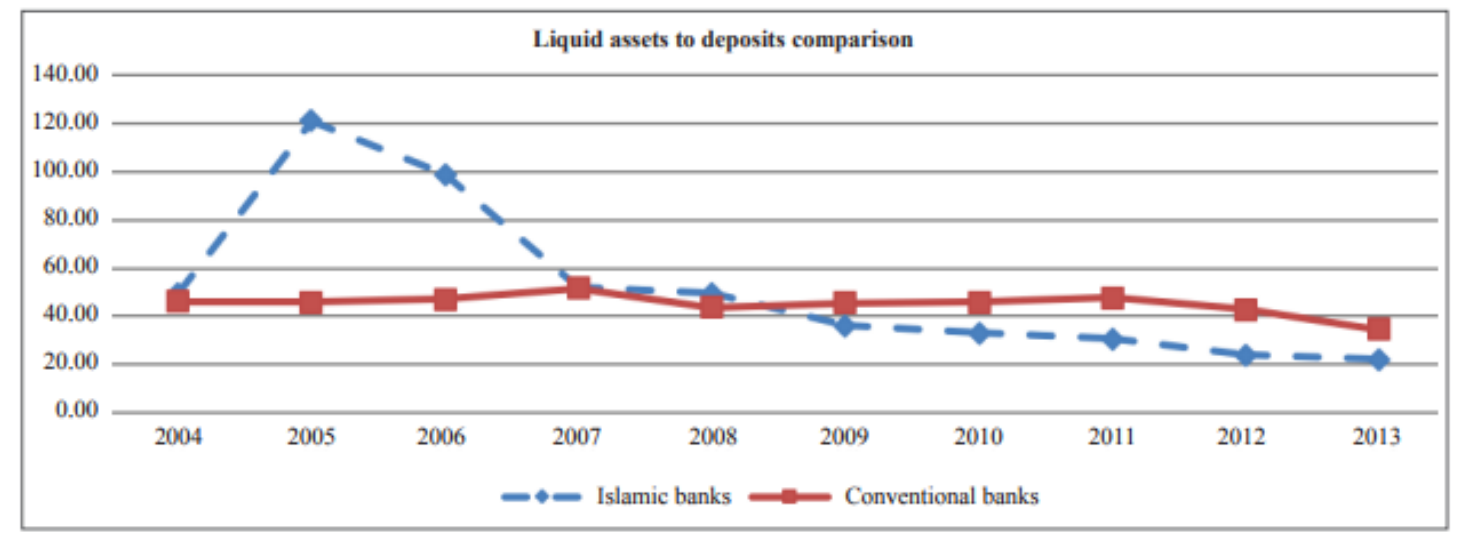

Figure 2. Liquid Assets to Deposits of Islamic and Conventional Banks in Malaysia (Wahid and Dar, 2016)

The conventional bank has a wide range of tools that can be used to manage their liquidity problems (Figure 2). Bacha and Mirakhor (2013) classifies them into two main components which are interbank deposit system and money market instrument. The interbank deposit system is a platform where banks can lend and borrow among themselves with a short tenure ranging from overnight up to a maximum of one year. These lending and borrowing activities charge an interest rate that we know as Kuala Lumpur Interbank Offer Rate (KLIBOR). The second component is money market instrument which allows banks to manage their liquidity through issuance or purchase of debt instruments. The instruments traded in this money market are short-term debt papers such as Malaysian Treasury Bills, BNM Bills, Malaysian Government Securities, Banker's Acceptances, Commercial Papers, and Repurchase Agreements (Repos). 
As expected, a majority if not all of the liquidity instruments available in the market are interest-bearing instruments which are not allowed to be traded by an Islamic bank. Thus, to cater the liquidity problems that might arise, Islamic banks are almost 50\% more liquid than the conventional bank (Majid and Rais, 2003). However, with the more advanced in Islamic banking industry, many countries have started to develop and engineer Islamic liquidity management instruments. These instruments are short-term financial assets that can be traded among Islamic banks such as interbank investment account, commodity murabaha, sukuk, and even establishment of Islamic Money Market in Malaysia.

The development of these liquidity instruments is mainly initiated at countries which have sufficient players of Islamic Banks. For countries with a small number of Islamic banks, they have little to no option than to trade with the central bank. Even so, not all central banks have financial instruments that meet sharia requirements as a final recourse for Islamic banks. Some countries with only a few Islamic banks or countries with conventional banks that offer Islamic windows product are left with no liquidity instrument available.

Table 1. Islamic Liquidity Management Instrument Across Countries

\begin{tabular}{cl}
\hline Country & \multicolumn{1}{c}{ Instrument Available } \\
\hline Malaysia & Islamic Interbank Money Market (IIMM) \\
& Government Investment Issues (GII) \\
& Islamic Commercial papers \\
& Bank Negara Malaysia Negotiable Notes (BNNN) \\
& Bursa Suq Al-Sila' (Commodity Murabahah) \\
& Pasar Uang Antar Bank (Mudhārabah Interbank Investment) \\
Indonesia & Fasilitas Pendanaan Jangka Panjang Syariah (Long term sharia \\
& financing by central bank) \\
& Sukuk Ijarah and Sukuk Al-Salam by Central Bank \\
Bahrain & Reliance on non-interest bearing excess reserve in central bank \\
& Global Commodity Finance (electronic islamic interbank \\
UAE & money market) \\
& Islamic Certificates of Deposit based on commodity \\
& murabahah \\
Pakistan, Brunei, & Short term sukuk ijarah \\
Singapore &
\end{tabular}


Several organizations were also established to foster the stability and liquidity management of Islamic banks such as Islamic Financial Service Board (IFSB), International Islamic Financial Market (IIFM), Liquidity Management Centre (LMC), and International Islamic Liquidity Management (IILM) (Sole, 2007). IFSB is an international organization that sets prudential standards and guiding principles to ensure the stability of Islamic financial service industry (IFSB, 2017). IFSB is taking the role of reviewing committee for the execution of Basel III standard in Islamic Banks. IIFM was created to establish a standardization of international Islamic financial market, research and reports on Sukuk, and develop an active secondary market that is crucial for liquidity management of Islamic banks.

LMC that was founded in 2002 regulated under the central bank of Bahrain was intended to facilitate the flow of investment funds between financial institutions and create an active Islamic interbank market (Abdullah, 2010). While IILM is the latest innovation by 9 central banks to issue shariacompliant financial instruments that aim to facilitate cross-border Islamic liquidity management (Kusuma and Silva, 2014).

\section{Issues in Current Islamic Liquidity Management Instruments}

Recognizing potential problems and inefficiency arising from liquidity issue, Islamic financial institutions have evolved and started to develop liquidity management tools to be traded among Islamic banks. These liquidity instruments and infrastructures are bound to some issues and challenges.

\section{Commodity Murabahah}

Commodity murabahah is one of the most used instrument to manage liquidity risk particularly in Gulf region (El Gamal, 2006). Malaysia has also initiated Bursa Suq Al-Sila, an international electronic commodity trading platform to facilitate commodity murabahah. The banks with surplus liquidity use commodity murabahah to earn some return from the excess cash that they have by buying commodity on a spot payment from a party in the commodity market, then sell it to another party on deferred payment basis with same 
markup price. While the banks with a shortage of liquidity can purchase commodities from a party in the commodity market on deferred payment with mark up price, then sell it to a third party on a spot payment for market price. This transaction is also known as tawarruq.

The use of commodity murabahah is not without controversy. Tawarruq contract has long been a debatable issue among scholars on its permissibility (Ahmed et al., 2012; Ismon, 2012; Ahmed and Aleshaikh, 2014; Ndiaye, 2017). After the similar contract (bay al-inah), has been deemed non-permissible, Islamic finance has evolved it to tawarruq by involving a third party into the equation. However, many believe that the ultimate consequence of the transaction is the same with bay al-nah and it is merely a hilah or ploy to legitimize riba (Noor and Azli, 2009). Not only that, commodity murabahah does not tie its transaction with any real economic value as the commodity traded are not used for production or consumption (Gholamreza et al., 2012). The commodity is not even physically moved from one storage to another as the whole transaction are done electronically. Furthermore, according to Ali (2013), the use of commodity murabahah has transformed from liquidity management tools into a source of fund. If this is done on a large scale, the missing link between financial and real economic sectors can lead to a systematic risk.

Another problem arising from commodity murabahah is the inability to trade in the secondary market. Once the commodity is sold or bought on deferred payment basis, it becomes debt which is not allowed to be sold unless at par value. Although scholars have different views on the permissibility of bay al-dayn or sale of debt at discount to a third party, Hanafi's, Shafi'i's (some), Hanbali's and Zahiri's scholars are on the opinion that selling it for a lesser value is similar to riba as the value of the payment is tied to the time (Amin, 2007). This inability to be sold in the secondary market makes commodity murabahah a less favorable option as a liquidity tools. The nature of liquidity management itself will require the instrument to be easily bought and sold on the secondary market to balance the liquidity position of the bank. 


\section{Interbank Deposit Placement}

Interbank deposit placement based on mudhärabah or wakalah is another recourse for Islamic Banks to place their excess liquidity (Sobol, 2013). However, this will only be possible for countries with many Islamic banks exist in the market, or else they would have no partner for the deposit placement. The interbank deposit placement is however not a preferred means by Islamic bank to manage their liquidity.

First, the deposit placed in other banks do not meet the criteria of HQLA. In order to meet the liquidity coverage ratio set by Basel III, placing liquidity excess in HQLA asset is important. Since the Islamic banks where the fund is put also faces liquidity problems, interbank deposit also subjects to counterparty risk where the other party (other Islamic banks) cannot meet the obligation when it is due.

Another significant problem with interbank deposit placement is the fact that banks liquidity position tends to move in a similar manner especially during a significant macroeconomic event. For example during a recession, most banks will short of liquidity and the interbank deposit will automatically disappear since banks do not have the excess fund to be deposited.

\section{Islamic Interbank Money Market}

Malaysia has pioneered the very first move in the formation of Islamic Interbank Money Market (IIMM) in the year 1994. IIMM acts as an intermediary between the surplus and deficit banks to channel their fund in order to maintain the liquidity position (Bacha, 2008). IMM has a total of twelve interbank investment and financial instruments with different underlying contracts and maturities (from overnight up to one-year placement). Since money market integrates banking system and capital market together, it also acts as a channel for monetary policy.

Although having an Islamic interbank money market is a big step forward, there are some issues and challenges faced by IIMM. The first latent problem arises is the usage of the conventional interest rate as a benchmark 
yield. Further according to Bacha (2008), in a dual banking system, Islamic banks which issuing IIMM instruments will face higher cost when the interest rate rises. However when the interest rate decline, the investors who held IIMM instruments will suffer a lower return than those who hold conventional money market instrument.

A discourse of developing an international Islamic interbank money market has been brought to bring benefit for the global Islamic finance. Unfortunately, this idea raises significant potential problems on its own. It will face regulatory issues, a high cost of transactions, taxes, currency fluctuation risk, and restriction on cross-border movement of capital. Until the moslem countries can come up with a strong union that removes all these hindrances, a cross-border Islamic money market will never be possible.

Table 2. Yearly Islamic Interbank Money Market Transaction (IIMM, 2017)

\begin{tabular}{|c|c|c|c|c|c|c|c|}
\hline \multicolumn{8}{|c|}{ Yearly Islamic Interbank Transactions } \\
\hline & 2011 & 2012 & 2013 & 2014 & 2015 & 2016 & 2017 \\
\hline Qard & $2,364,646$ & $1,627,437$ & $1,710,800$ & $1,691,752$ & $2,307,740$ & $2,800,673$ & $2,762,559$ \\
\hline Murabahah & 56,874 & 55,423 & 26,571 & 71,827 & 244,585 & 135,089 & 68,155 \\
\hline & $2,421,521$ & $1,682,860$ & $1,737,372$ & $1,763,579$ & $2,552,325$ & $2,935,762$ & $2,830,714$ \\
\hline Interbank & 304,515 & 399,631 & 441,803 & 418,582 & 90,533 & 164,787 & 227,448 \\
\hline NIDC/INID & 26,832 & 32,811 & 46,061 & 62,381 & 61,746 & 49,715 & 55,752 \\
\hline $\begin{array}{l}\text { IMTN/IAB/ } \\
\text { IPDS/ICP }\end{array}$ & 67,164 & 108,092 & 92,623 & 72,403 & 86,721 & 125,915 & 99,459 \\
\hline MITB & 528 & 2,341 & 2,187 & 4,050 & 8,157 & 7,833 & 3,809 \\
\hline $\begin{array}{l}\text { BNNN/ } \\
\text { BNMN/ } \\
\text { SBNMI }\end{array}$ & 235,734 & 312,791 & 377,363 & 296,012 & 43,549 & 62 & - \\
\hline GII/SPK & 239.810 & 223,068 & 226,484 & 187,462 & 233,767 & 334,346 & 229,281 \\
\hline TOTAL & $3,296,106$ & $2,761,596$ & $2,923,895$ & $2,804,473$ & $3,076,799$ & $3,618,423$ & $3,446,466$ \\
\hline
\end{tabular}

Salam and Ijarah Sukuk

The second most familiar instrument traded as liquidity management is Sukuk. The widely used contract for Sukuk used as liquidity tools is salam dan ijarah contracts. Among countries that use Sukuk are Bahrain, Pakistan, Turkey 
and Indonesia. Most of the Islamic banks in these countries trade sukuk that are issued by the central bank or government. The usage of Sukuk is seen to be superior compared to commodity murabahah as Sukuk is mostly issued to finance real and specific projects. However the volume of issuance is still quite small and in the case of Salam Sukuk, it is not allowed to be traded on the secondary market as it would lead to bay al-dayn.

The limited number of issuance makes it difficult to have sufficient sukuk to be traded in the market. Besides the limited number of sukuk issued, most of sukuk issued by the government is a long-term maturity since the project being financed are mostly medium-long term. A new initiative had been taken to issue a short-term international sukuk with the establishment of International Islamic Liquidity Management (IILM). Another possible problem is sharia issue in ijarah sukuk on the benevolent and legal ownership between sukuk holders and issuers. Some scholars believe that the sukuk holders should be given both benevolent and legal ownership as they are the true owners of the asset.

\section{IILM Short-Term Sukuk}

Since August 2013, IILM has started issuing USD denominated, shortterm and A-1 SandP rating, sharia-compliant sukuk. It is the first shariacompliant money market instruments that use a sovereign asset-backed type of Sukuk. The IILM is traded globally and has an active secondary market through the primary dealer networks that it formed. Since it is an effort by several central banks, it receives favorable regulatory treatments from its member of central banks. IILM sukuk also fulfill the criteria of HQLA which will help Islamic Banks to meet Basel III requirements while still earning some returns from holding the instrument. Onal (2013) mentioned that IILM sukuk has the potential to create its yield as a new benchmark curve pricing for Islamic finance industry to replace conventional interest rate.

Albeit its future potential as a highly liquid cross-border tradable instrument, IILM sukuk also faces some challenges. As the sukuk relies on the 
sovereign asset to be securitized for its issuance, it is bound to the limitation of a number of sovereign assets available. A government would not be willing to securitize too many of its national asset as it will be harmful to the stability of the country. Archer and Karim (2014) explained that it would be difficult to find countries who are willing to sell their sovereign asset and buy it at a higher price.

IILM sukuk also subjects to some sharia issues on the genuineness of sales and lease in its ijarah contract. The sukuk holders do not know the asset being traded as the issuers do not declare specifically which asset is being securitized, this could lead to a potential gharar issue as the subject matter of the contract is not known by the party. Not only that, the benevolent and legal ownership status is given to the sukuk holders is also a potential problem that might arises in ijarah sukuk.

There is a possibility of a timing mismatch between the duration of IILM sukuk asset and liability. The underlying asset of IILM sukuk is generally medium to long-term asset like infrastructure financing, although there could be short term asset like commodity murabaha. However, the IILM sukuk itself is short term. The nature of the underlying assets in IILM sukuk are different from the purpose of usage by the sukuk holders which is for liquidity management.

This could lead to a problem with its coupon and principal payment. Although IILM has allocated a time reserve of $2 \%$ amount from issuance to counter this potential problem, it still opens the possibility of inability to meet the obligation on time. This is a crucial issue for liquidity management instrument. Lastly, while the usage of USD denominated sukuk will benefit Islamic banks with limited liquidity instrument available in their country. However, it will also expose them to exchange rate fluctuation risk as the banks have to convert the USD to their local currency to meet domestic liquidity needs. 


\section{Towards a Beter Liquidity Management in Islamic Banking}

In pursuance of a better liquidity management, Islamic banks have to redefine how they do business and operate their asset and liability. As mentioned earlier in this paper, an ideal Islamic bank that practices profit and loss sharing contract in the business will not suffer from liquidity risk. Thus, imposing the usage of PLS contract in both funding and financing will minimize the mismatch maturity between the two side of balance sheet. The cash inflow and outflow of asset and liability will move simultaneously as both parties share the risk of the project. Bank will only act as intermediaries without guaranteeing demand payment from depositors.

Islamic banks can also apply maturity matching strategies between their asset and liabilities. This could be done by channeling short-term funds to finance short-term projects, while long-term funds can be used to finance longterm projects (Mirakhor et al., 2012). This strategy would allow Islamic banks to match the cash flow timing between their depositors and borrowers.

It is also important to institutionalized liquidity risk governance in the banking structure to oversee liquidity position and take appropriate measures when needed. This could be done by having a special committee for liquidity management supported by sharia committee to oversee the sharia compliance of liquidity management instruments that the bank uses. Another important action to be taken is enacting Basel III requirements in banking policy following the United Kingdom, the United States, and the European Union. Since Basel III is policy recommendation, its execution is not binding. Only if the central banks enact it in the banking policy, it becomes an enforceable law and forces all banks to meet the standards.

It is important for Islamic finance industry to keep their focus on the development of sharia-compliant liquidity management instrument. This is done to introduce a wide range instruments in regards to the maturities, features, and contracts. Having an extensive diversity of instruments will allow Islamic banks to choose the best instruments to meet their unique liquidity needs. Not only issuing a wide variety of instruments, promoting an active 
secondary market is equally essential. In order to foster the activity in the secondary market, all stakeholders have to take apart. Having an efficient, transparent and trustable secondary market will attract a wide pool of players which can facilitate the liquidity needs of Islamic banks.

The central bank should also play their role in this issue. For countries with little to no liquidity instrument available, the central bank should be able to be the last resort of lender should the Islamic bank faces liquidity problems. An interest-free instrument should be made available as a final recourse for Islamic banks. Not only that, it would also be an advantage for Islamic banks if Central banks hold certain eligible sukuk or other instruments as a part of the statutory reserve requirement of Islamic banks. This would allow Islamic banks to gain some earning from the idle cash of the reserve management.

In order to achieve a more stable and robust global Islamic financial industry, we need to reinforce the global cooperation among moslem countries. Among real actions that can be taken are as follows. First, having a global sharia board issuing fatwa that binds all moslem countries will smooth the cooperation and cross-border trading of liquidity instruments. Although we already have AAOIFI sharia standard, it is not an international fatwa that is accepted by all moslem countries in conducting their Islamic finance practices. In reality, each country issues a different fatwa which makes it difficult to create cross-border initiatives.

Second, there is a need for standardization of regulatory, pricing benchmark, and tax framework. By having a standardized practice of these, it would make it easier for transaction among jurisdictions. It will also enhance the competitiveness of Islamic financial industry which will attract players from outside industry as well. Lastly, to cultivate an international interbank money market among Islamic banks, the restrictions of capital movement between moslem countries should be removed. 


\section{Conclusion}

Seeing the nature of the business, liquidity risk is among the top priority concern of banking industry. The magnitude of the problem is even bigger for Islamic banks as the liquidity management instruments available are limited. Previously, Islamic banks tend to hold more liquid asset than the conventional bank which impacts badly on its profitability and efficiency. Now, with the advancement and development of Islamic financial service industry, the infrastructure and tools for liquidity management have evolved rapidly. However, current liquidity instruments are bound to challenges pertaining its sharia issue, inactivity of its secondary market, key issues on shotrt term issuance and difficulty of cross-border transactions.

This study is important for the key stakeholders to take appropriate policy and action. With regard to managing a better liquidity, it is important for Islamic banks to promote the usage of PLS contracts in both asset and liability of Islamic banks. Having a specific committee to oversee day to day liquidity position in the bank will help Islamic banks have a better management of their liquidity. The banking regulator shall also enact Basel III requirements in banking policy would to foster the stability and liquidity management in Islamic banks. A wider diversity of liquidity instruments with different maturities, features and contracts are needed. Besides that, promoting an active secondary market is just as important as developing the tools. The central bank should also play its role as the last resort of lender and place reserve requirements in profitable instruments. Lastly, the global cooperation among moslem countries should be reinforced to promote international interbank money market.

\section{References}

Abdullah, D. V. (2010). Liquidity Management in Institutions Offering Islamic Financial Services. In Second Islamic Financial Stability Forum, Vol. 14.

Ahmed, E. R., Yahaya, S., and Harashid, M. (2012). Shubuhat on Matter of Bai'alinah and Tawarruq. International Journal of Business and Technopreneurship, Vol. 2(1): 85-101. 
Ahmed, H., and Aleshaikh, N. M. (2014). Debate on Tawarruq: Historical Discourse and Current Rulings. Arab Law Quarterly, Vol. 28(3): 278-294.

Ali, S. S. (2013). State of Liquidity Management in Islamic Financial Institutions. Islamic Economic Studies, Vol. 21(1): 63-98.

Amin, H. (2007). An Analysis of the Classical and Contemporary Juristic Opinions on Bay al-Dayn. Labuan e-Journal of Muamalat and Society, Vol. 1: 29-40.

Archer, S., and Karim, R. A. A. (2014). The IILM Short-term Sukūk for Liquidity Management: A Success Story in Enhancing Financial Stability. SEACEN Financial Stability Journal, Vol. 3: 11-23.

Bacha, O. I. (2008). The Islamic Inter Bank Money Market and a Dual Banking System: the Malaysian Experience. International Journal of Islamic and Middle Eastern Finance and Management, Vol. 1(3): 210-226.

Bech, M., and Keister, T. (2017). Liquidity Regulation and the Implementation of Monetary Policy. Journal of Monetary Economics, Vol. 92: 64-77.

Beck, T., Demirgüç-Kunt, A., and Merrouche, O. (2013). Islamic vs. Conventional Banking: Business Model, Efficiency and Stability. Journal of Banking and Finance, Vol. 37(2): 433-447.

BIS. (2009). International Framework for Liquidity Risk Measurement, Standards and Monitoring. Consultative Document, Basel Committee on Banking Supervision.

Bordeleau, É., and Graham, C. (2010). The Impact of liquidity on Bank Profitability (No. 2010, 38). Bank of Canada working paper.

Brown, M., Trautmann, S. T., and Vlahu, R. (2016). Understanding Bank-Run Contagion. Management Science, Vol. 63(7): 2272-2282.

Bryant, J. (1980). A Model of Reserves, Bank Runs, and Deposit Insurance. Journal of Banking and Finance, Vol. 4(4): 335-344.

Calomiris, C. W., and Gorton, G. (1991). The Origins of Banking Panics: Models, Facts, and Bank Regulation. In Financial Markets and Financial Crises: 109174. University of Chicago Press.

Calomiris, C. W., and Mason, J. R. (1994). Contagion and Bank Failures During the Great Depression: The June 1932 Chicago Banking Panic (No. w4934). National Bureau of Economic Research.

Comptroller of the Currency (2001). Liquidity: Comptroller's Handbook. Comptroller of the Currency: Administrator of the National Banks. Washington, DC.

Dar, H. A., and Presley, J. R. (2000). Lack of Profit Loss Sharing in Islamic Banking: Management and Control Imbalances. International Journal of Islamic Financial Services, Vol. 2(2): 3-18. 
Deloit. (2011). Deloitte Middle East Islamic Financial Survey: Benchmarking Practices.

Diamond, D. W., and Dybvig, P. H. (1983). Bank Runs, Deposit Insurance, and Liquidity. Journal of political economy, Vol. 91(3): 401-419.

El-Gamal, M. A. (2006). Islamic Finance: Law, Economics and Practice. Cambridge: Cambridge University Press.

Eljelly, A. M. (2004). Liquidity-Profitability Tradeoff: An Empirical Investigation in an Emerging Market. International Journal of Commerce and Management, Vol. 14(2): 48-61.

Elliott, D. J. (2014). Bank Liquidity Requirements: An Introduction and Overview. The Brookings Institution.

Gholamreza, Z., Ariffin, N. M., and Shahabi, A. (2012). Some Issues on Murabahah Practices in Iran and Malaysian Islamic Banks. African Journal of Business Management, Vl. 6(24): 7066-7073.

Gomes, T., and Khan, N. (2011). Strengthening Bank Management of Liquidity Risk: The Basel III Liquidity Standards. Bank of Canada Financial System Review, Vol. 5: 35-42.

Härle, P., et al. (2010). Basel III and European Banking: Its Impact, How Banks Might Respond, and The Challenges of Implementation. EMEA Banking: 16-17.

Hayali, A., Sarili, S., and Dinc, Y. (2012). Turkish Experience in Bank Shareholders' Fraud and Bank Failure: Imar Bank and Ihlas Finans Case. The Macrotheme Review, Vol. 1(1): 115-129.

Hong, H., Huang, J. Z., and Wu, D. (2014). The Information Content of Basel III Liquidity Risk Measures. Journal of Financial Stability, Vol. 15: 91-111.

IFSB. (2017). Background. Retrieved from: http:/ / www.ifsb.org/background.php. December 18, 2017

IFSB. (2017). Basel III Regulatory Reforms and Islamic Finance discussed at the 15th Islamic Financial Stability Forum. Retrieved from: http:/ / www.ifsb.org/press_full.php?id=384andsubmit=more.

December 18, 2017

IIMM. (2017). Yearly Islamic Interbank Transactions. Retrieved from: http:/ /iimm.bnm.gov.my/index.php?ch=15andpg=86. December 18, 2017.

Ismon, N. Y. B. (2012). Legality of Tawarruq in Islamic Finance. Tazkia Islamic Finance and Business Review, Vol. 7(1).

Kashyap, A.K., Rajan, R. and Stein, J.C. (2002). Banks as Liquidity Providers: An Explanation for The Coexistence of Lending and Deposit-taking. The Journal of Finance, Vol. 57(1): 33-73. 
Kusuma, K. A., and Silva, A. C. (2014). Sukuk Markets: a Proposed Approach for Development. The World Bank.

Majid, A., and Rais, A. (2003, March). Development of Liquidity Management Instruments: Challenges and Opportunities. In International Conference on Islamic Banking: Risk Management, Regulation and Supervision, held in Jakarta Indonesia September.

Mirakhor, A., Krichene, N., and Shaukat, M. (2012). Unsustainability of the Regime of Interest-Based Debt Financing. ISRA International Journal of Islamic Finance, Vol.4(2): 25-52.

Muranaga, J. and Ohsawa, M. (2002). Measurement of Liquidity Risk in the Context of Market Risk Calculation. Working Paper, Institute for Monetary and Economic Studies, Bank of Japan, Tokyo.

Ndiaye, H. S. F. Y. N. D. (2017). Issues with the Use of Tawarruq in Malaysia. Journal of Islamic Banking and Finance, Vol. 5(2): 30-36.

Noor, A., and Azli, R. (2009). A Review of Islamic Credit Card Using Bay' al-'Inah and Tawarruq Instrument as Adopted by Some Malaysian Financial Institution. Retrieved July 24, 2016, from http:/ / www.maybank2u.com.my/iwovresources/islamicmy/document/my/en/islamic/scoe/knowledgecen tre/researchpaper/A_Review_of_Islamic_Credit.pdf

Nymag. (2017). A History of Bank Runs. Retrieved November 29, 2017 http:// nymag.com/news/intelligencer/topic/banks-2012-6/

Olagunju, A., David, A. O., and Samuel, O. O. (2012). Liquidity Management and Commercial Banks' Profitability in Nigeria. Research Journal of Finance and Accounting, Vol. 2(7-8): 24-38.

Onal, M. (2013). Islamic Liquidity Management: The Way Forward.

Postlewaite, A., and Vives, X. (1987). Bank Runs as an Equilibrium Phenomenon. Journal of Political Economy, Vol. 95(3): 485-491.

Samad, A., and Hassan, M. K. (1999). The Performance of Malaysian Islamic Bank During 1984-1997: An Exploratory Study. International Journal of Islamic Financial Services, Vol. 1(3): 1-14.

Shearman and Sterling. (2011). The New Basel III Framework: Implications for Banking Organizations. Financial Institutions Advisory and Financial Regulatory.

Sobol, I. (2013). Liquidity Management Practices in Islamic Banking. Zarządzanie i Finanse, Vol. 2(1): 1.

Sole, M. J. (2007). Introducing Islamic Banks into Conventional Banking Systems (No. 7-175). Working paper, International Monetary Fund.

The Economist. (2017). The Bank that Failed. Retrieved November 28, 2017 from http:/ / www.economist.com/ node/9832838 
TIFBR | Tazkia Islamic Finance and Business Review

Volume 12(2), 2018

Wahid, M. A., and Dar, H. (2016). Stability of Islamic Versus Conventional Banks: A Malaysian Case. Jurnal Ekonomi Malaysia, Vol. 50(1): 111-132.

Waldo, D. G. (1985). Bank Runs, the Deposit-currency Ratio and the Interest Rate. Journal of Monetary Economics, Vol. 15(3): 269-277. 